\title{
Öznel Sosyal Sınıflar ve Ekonomik Eşitsizlikler Hakkındaki Görüşler
}

Anıl DUMAN, Department of Economics, Faculty of Economics and Administrative Sciences, Yasar University, Turkey; e-mail: anil.duman@yasar.edu.tr

\section{Subjective Social Class and Opinions on Economic Inequality}

\begin{abstract}
The tolerance for economic inequalities displays remarkable differences among countries including Turkey. While in some countries the shifts in inequality are accepted more easily, in others the demand for redistributive policies went up rapidly. This study aims to examine the reasons for changing opinions on inequality among people even when there are no transformations in their economic positions. Besides economic, social, institutional and normative indicators the study shows that subjective class status is also explanatory for redistributive preferences. The study also found that in Turkey the share of people identifying themselves with middle class increased over time, which decreased the redistributive preferences in comparison to earlier periods.
\end{abstract}

Keywords : Redistribution, Social Policy, Preference Formation, Income Distribution.

JEL Classification Codes : $\quad$ D31, D63, H23.

\section{Öz}

Ekonomik eşitsizliklere olan tahammülün yıllar içerisindeki seyri Türkiye'nin de dâhil olduğu ülkeler arasında oldukça büyük farklılıklar göstermektedir. Bazı toplumlarda artan eşitsizlikler daha kolaylıkla kabul görürken diğer toplumlarda yeniden bölüşüm politikalarına olan talep hızlı bir yükseliş göstermiştir. Bu çalışma bireylerin ekonomik pozisyonlarında bir dönüşüm gözlenmemesine rağmen zaman içerisinde eşitsizliğe dair görüşlerinin neden değiştiğini açıklamayı amaçlamaktadır. Çalışmada, ekonomik, sosyal, kurumsal ve normatif göstergelerin yanısıra kişilerin kendilerini hangi sosyal sınıfa ait hissettiklerinin de gelir dağılımı tercihlerini etkilediği gösterilmiştir. Ayrıca çalışma Türkiye'de yıllar içerisinde kendisini orta sınıfta görenlerin oranının artması ile birlikte gelir dağılımı hakkındaki görüşlerin de değiştiğini ve daha adil bir gelir dağılımı tercihinin önceki dönemlere göre gerilediğini ortaya koymaktadır.

Anahtar Sözcükler $\quad$ : Yeniden Bölüşüm, Sosyal Politika, Tercih Oluşumu, Gelir Dağılımı. 


\section{Giriş}

Ekonomik eşitsizlikler ve bireylerin bu eşitsizlikler hakkındaki görüşleri hem zaman içerisinde hem de ülkeden ülkeye değişmektedir. Bazı toplumlarda bireyler eşitsizlikleri var olan ekonomik sistemin olağan bir sonucu olarak kabul edip tahammül gösterirken bazı toplumlarda eşitsizliklere karşı yeniden bölüşüm politikaları üretilmesi gerektiğini savunmaktadırlar. Toplumlar arası bu farklılıkların yanısıra zaman içerisinde de bireyler ekonomik eşitsizliklere karşı daha toleranslı olabilmektedirler. Bu alanda yapılan çalışmalar neden bazı toplum ve bireylerin diğerlerine oranla eşitsizlikler karşısında daha toleranslı olduğunu açıklamak için nesnel ve öznel etmenlere bakmışlardır. Nesnel faktörler bireylerin sosyo-ekonomik konumları, refah devleti politikaları ve kurumları içerirken öznel faktörler sosyal adalet hakkındaki görüşler, ekonomik geçişkenliğe olan inanç ve ait hissedilen sosyal grupları kapsamaktadır.

Bu çalışma bireylerin nesnel koşullarında bir dönüşüm gözlenmemesine rağmen zaman içerisinde eşitsizliğe dair görüşlerinin neden değiştiğini açıklamayı amaçlamaktadır. Türkiye örnek alınarak öznel sınıf konumunun bireylerin gelir dağılımı hakkındaki görüşlerine etkisi incelenmiştir. Sosyal sınıflar her ne kadar nesnel etmenler tarafindan belirlense de bireyler kendilerini öznel olarak ait olmadıkları bir sınıfa bağlı hissedebilirler. Böyle durumlarda gelir ve risk dağılımındaki konumlarından bağımsız ve hatta bu konumlarla çelişen yeniden bölüşüm tercihlerinde bulunabilirler. Çalışma, Türkiye'de 1990'lardan itibaren gelir adaleti olması gerektiğini savunanlarının oranında bir düşüş olduğunu ve bu düşüşün kısmen kendisini orta sınıfta görenlerin oranının artması ile açıklanabileceğini öne sürmektedir. Öznel olarak orta sınıfta konumlanan bireyler yıllar içerisinde artan bir biçimde eşitsizliklerin ekonomik rekabete yardımcı olduğunu ve devletin bireylere bakmak konusunda daha az sorumluluk sahibi olması gerektiğini beyan etmektedirler. Üstelik orta sınıfa kayış emek piyasalarındaki durum ve gelir dağılımı gibi nesnel faktörler tarafindan da desteklenmemektedir.

İlerleyen bölümde gelir dağılımı tercihlerine dair var olan bazı çalışmalar ile beraber Türkiye'deki gelir dağılımı tercihlerinin zaman içerisindeki seyri sunulmaktadır. Üçüncü bölümde çalışmada izlenilen yöntem ve kullanılan veriler açıklanmıştır. Dördüncü bölüm Türkiye'de gelir dağılımına dair bireysel görüşlerin zaman içerisinde nasıl değiştiğine ve öznel sınıf konumunun bu tercihlere olan etkisi tartışmıştır. Son bölümde çalışmanın bulguları özetlenmiş ve bazı politika önermelerinde bulunulmuştur. 


\section{Gelir Dağılımı Görüşlerini Etkileyen Faktörler ve Türkiye’de Öznel Sinıf Konumu}

Yaygın olarak kabul görmüş ekonomik modellere göre bireyler yeniden bölüşümü çıkarlarına hizmet ettiği ve bu tip programların beklenen faydaları beklenen maliyetlerinden fazla olduğu müddetçe desteklerler (Meltzer \& Richard, 1981; Moene \& Wallerstein, 2001). Bu faydalar sadece geliri artırmakla değil emek piyasasındaki riskleri azaltmakla da gerçekleşebilir (Duman, 2009). Ampirik olarak bu modeller eşitsizlik ile yeniden bölüşüm talepleri arasında doğrudan bir ilişki öngörmektedirler. Bunun ana sebebi gelir adaletsizliğinin fazla olduğu toplumlarda medyan seçmenin alt gelir grubuna ait olması ve dolayısıyla yeniden bölüşüm politikalarından net fayda sağlamasıdır. Aynı öngörü risk dağılımı için de geçerlidir ve riskli konumda bulunan bireylerin sosyal korumaya daha fazla destekçi olması beklenmektedir Fakat bu önermeler gerçek verilerce desteklenmemektedir ve eşitsizliğin görece yüksek olduğu bazı ülkelerde yeniden bölüşüm politikalarına verilen desteğin oldukça düşük seviyelerde seyrettiği gözlemlenmiştir. Alt gelir grubuna mensup ve bu tip politikalardan yarar görebilecek insanlar programların karşısında bir tavır sergilerken bu politikaları finanse eden ve net bir çıkarı olmayan üst gelir grubuna mensup bazı kişiler aksi yönde hareket etmektedirler. En az bunun kadar önemli başka bir ampirik bulgu da gelir ve yeniden bölüşüm arasındaki ilişkinin zaman içerisinde dönüştüğüdür. Aynı bireyler ele alınan döneme bağlı olarak sosyal politika yanlısı ya da karşıtı olabilmektedirler.

Literatürde ampirik bulgularla teorik modeller arasındaki bu uyuşmazlığı açıklamak için bazı önermeler sağlanmıştır. Bazı araştırmacılar tarafından bireysel yeniden bölüşüm tercihlerinin nesnel sosyo-ekonomik durumun değil öznel etmenlerin belirlediği iddia edilmiştir (Ravallion \& Lokshin, 2000). Örneğin, kişiler nesnel ekonomik konumlarından bağımsız olarak çevrelerindeki kişilere göre görece durumları doğrultusunda kararlar verebilmektedirler. Bazı diğer incelemelere göre ise sosyal geçişkenliğe olan inanç ve sosyal olarak yükselmenin mümkün olduğu hakkındaki kanı alt gelir gruplarında olsa dahi bireylerin yeniden bölüşüme destek vermemesi sonucunu doğurmaktadır (Benabou \& Ok, 2001). Dolayısıyla, kişiler politika tercihlerini gerçek gelir ve risk dağılımındaki konumlarının yanısıra beklentileri ve kendilerini toplumda gördükleri yere göre de biçimlendirmektedirler. Ve elbette hem beklentiler hem de görece konum zaman içerisinde ülke ve bireysel koşullar sonucu değişebilmektedir. Örneğin, kriz dönemlerinde yukarıya doğru sosyal bir geçişkenlik olacağına dair inanç azalırken hızlı büyüme dönemlerinde bu görüş artmaktadır.

Ayrıca, ülkede var olan sosyal koruma sistemi, vergi ve transferler sonrası gelir ve risk profilleri yoluyla hem insanların beklentilerini hem de nesnel koşullarını değiştirebilir. Örneğin, sosyal demokrat rejimlerde kişisel özellikler ve ekonomik başarısızlık arasındaki bağ zayıflarken liberal rejimlerde bu bağ oldukça güçlüdür ve bireyler 
ekonomik konumlarından sorumlu tutulurlar (Breen, 2004). Sosyal korumanın olmadığ1 toplumlarda bireyler arasındaki farklar daha belirgin ve aşılması daha zor olabilir. Bunun yanısıra kurumların insanların uzun dönemde beklentilerini ve nasıl bir toplumda yaşamak istediklerine dair fikirlerini dönüştürme ihtimali vardır. Sosyalizm gibi eşitlik yanlısı siyasi sistemler altında yaşamış bireylerin yeniden bölüşüm programlarına daha çok taraftar olmaları beklenmektedir (Gijsberts, 2002; Suhrcke, 2001). Bu bakımdan, kişisel tercihler incelenirken ülkenin siyasi tarihi ve refah rejimi de göz önünde bulundurulmalıdır. Türkiye'de de araştırılan dönemde sosyal yardımların niteliği ve niceliğinde önemli değişimler gözlenmiştir. Fakat ayni ve nakti yardımlardaki artışların bireylerin gelir adaletsizliği hakkındaki görüşlerine ne yönde etki edeceği tartışma konusudur. Sosyal politikalar bir yandan bireyleri piyasanın yarattığı olumsuzluklara karşı koruyarak daha dirençli hale getirirken diğer yandan başkalarının yoksunluklarına da daha duyarlı hale getirebilmektedir.

Kişilerin kendi sosyal pozisyonları ve bununla belirlenmiş eşitlik görüşlerine ek olarak kendilerini hangi sosyal gruba ait hissettikleri ve grup dışındakiler hakkındaki fikirleri de hem ülkeler hem de yıllar içerisindeki yeniden bölüşüm taleplerindeki farkları açıklamaktadır. Öznel kategorilerin özellikle sosyal politika ve oy tercihleri konusundaki yararlılığını gösteren birçok inceleme mevcuttur (Armingeon, 2006). Alt ve üst sınıflar için hem nesnel hem de öznel konumlandırma eğitim, gelir, meslek, emek piyasasındaki konum gibi faktörlerle belirlenirken orta sınıf için nesnel ve öznel durum arasında farklılıklar görmek mümkündür (Hout, 2008). Sosyal grupların bir hayli belirgin olduğu ve gruplar arası sosyo-ekonomik mesafenin fazla olduğu toplumlarda daha az sosyal dayanışma beklenmektedir (Alesina \& Angeletos, 2005). Buna göre, bu toplumlarda yeniden bölüşüm politikaları ancak grup üyelerine yaradığı sürece desteklenmektedir ve üyeler diğerlerinden kolayca ayrışabildiği için de üye olmayanları gözeten sosyal politikalara karşı durmak mümkündür.

Sosyal grupların daha az belirgin olduğu ve kişilerin kendilerini güçlü bir şekilde yalnızca bir toplulukla özdeşleştirdiği ülkelerde eşitsizliklere daha fazla tolerans gösterilir ve bireylere asgari yaşam koşullarını sağlama konusunda daha fazla sorumluluk atfedilir. Örneğin, 1rksal gruplara bağlılık Amerika Birleşik Devletleri'nde hem düşük hem de yüksek gelirli bireyler arasında yeniden bölüşüm tercihleri için kilit teşkil etmektedir. Sahip olunan maddi imkânlardan bağımsız olarak karşıt ırktaki insanların faydalanabileceği sosyal koruma programlarına karşı çıkıldığı gözlemlenmiştir (Luttmer, 2001). Burada gruplar arası ayrışmanın belirleyicisi ırktır ama başka toplumlarda bu, etnik kimlik, din, gelir düzeyi ya da coğrafi bölgeler de olabilir. Grupların hangi kimlikler çatısı altında oluştuğu ve birbirlerine karşı nasıl konumlandıkları ulusual şartlara bağlıdır. 
Gelişmekte olan ülkeler arası karşılaştırmalar yapan çalışmalarda Latin Amerika bölgesinde yeniden bölüşüm taleplerinin bir hayli yüksek olduğu ortaya konmuştur. Fakat bu taleplere karşılık gelecek sosyal politikalar uygulanmamaktadır. Talepleri açıklamada nesnel göstergelerden ziyade öznel değişkenler daha uygundur ve insanlar tercihlerine algıladıkları sosyal konum ile yön vermektedir (Ardanaz, 2009). Bazı toplumlarda bireysel çıkarlarlar ile tezat oluşturabilecek ve sosyal politika seçimlerini şekillendirebilecek dini ve kültürel etmenlerin baskın olduğu gözlenmiştir (Dion, 2010). Yoksulluğun sebeplerine dair inanışlara bakıldığında gelişmiş ülkelere benzer bulgulara rastlanmıştır. Refah ve ekonomik başarıların kişisel çabalarla elde edilebileceği ve sistematik olarak bir adaletsizlik olmadığ görüşü insanları gelişmekte olan ülkelerde de daha az yeniden bölüşüm talep etmeye teşvik etmektedir (Patti ve Navarra, 2010). Bu bakımdan, hem nesnel hem de öznel göstergelerin ampirik analizlerde kullanılması ve kişilerin sosyo-ekonomik bakımdan kendilerini nerede gördüklerinin anlaşılması sosyal politikaların tercihler üzerindeki etkisini açıklamakta gereklidir. Bahsedilen çalışmalarda bu analizler bireysel düzeyde kalmıştır ve öznel değişkenler ile sosyal adalet hakkındaki düşünceler ve grup aidiyeti ile arasında bir ilişki kurulmamıştır.

Önerilen çalışma yukarıda sözü edilen bireysel politika tercihi belirleyecilerine ek olarak öznel sosyal sınıfları da açıklayıcı değişken olarak ekleyerek katkı sunma amacını gütmektedir. Türkiye gibi birçok ülkede zaman içerisinde yeniden bölüşüm talepleri ve eşitsizliğe olan tahammül değişmiştir ve çalışmada bu değişimin ana sebebi olarak kişilerin sınıf aidiyetleri gösterilmiştir. Yıllar içerisinde bazı toplumlar artan ekonomik eşitsizlikleri olağan kabul ederken bazı toplumlar bu eşitsizlikleri azaltmak için yeniden bölüşüm politikaları talep etmişlerdir. Örneğin, Türkiye'de 1990'lı yıllarda katılımcıların \%29.4'ü gelirlerin daha eşit dağılması gerektiğini savunurken 2000'li yıllarda bu oran \%17.9'a gerilemiştir. Benzer bir gelişme devletin asgari geçimi sağlamadaki sorumluluğu fikri için de geçerlidir. Yine 1990'lı yıllarda katılımcıların \%27.5'i bu görüşe katılırken, 2000'li yıllarda katılımcıların sadece \%17.1'i devletin sorumluluğundan bahsetmektedir (WVS.org, 1989-2011). Oysa Arjantin ve Fas gibi ülkelerde bunun tam aksi bir değişim hâkimdir ve eşitsizliğe olan tahammül aynı yıllar içerisinde azalmıştır. Ayrıca katılımcıların daha büyük bir kısmı devletin bireyler için asgari yaşam standartlarını sağlamakla yükümlü olduğunu belirtmiştir.

Şekil: 1'de hem gelir adaleti hem de devletin bireylerin asgari yaşam koşullarını sağlama sorumluluğu hakkındaki görüşlerin yıllar içerisindeki seyri görülmektedir. Anketin gerçekleştirildiği dönemler arasında hem gelir dağılımının daha eşit olması gerektiği görüşüne katılanların hem de devletin asgari ihtiyaçları karşılaması gerektiğini belirtenlerin oranında 2000'lerin başına kadar bir artış daha sonra ise hızlı bir azalış gözlenmektedir. Daha fazla gelir adaleti olmasını isteyenlerin oranı \%29'dan dönem sonunda \%17'ye gerilerken devlet daha fazla sorumluluk üstlenmelidir diyenlerin payı tüm katılımcilar içerisinde \%26'dan yine aynı dönemde \%14'e düşmüştür. Gelir adaleti ve devlet 
sorumluluğu hakkındaki görüşlere katılımın en yüksek olduğu dönem Türkiye'de 20002004 anket dönemindedir. Bu dönemin depremden hemen sonrasını ve krizi kapsadığı için yeniden bölüşüm taleplerinin daha yüksek olması beklentiler ile uyumludur. Fakat bir sonraki dönemde bireyler gelir adaleti ve asgari yaşam koşullarını sağlamada devletin yükümlülüğü gibi yeniden bölüşümü destekleyici görüşlerden bir hayli uzaklaşmışlardır.

\section{Şekil: 1}

\section{Gelir Adaleti ve Devletin İhtiyaçları Karşılamadaki Sorumluluğu}

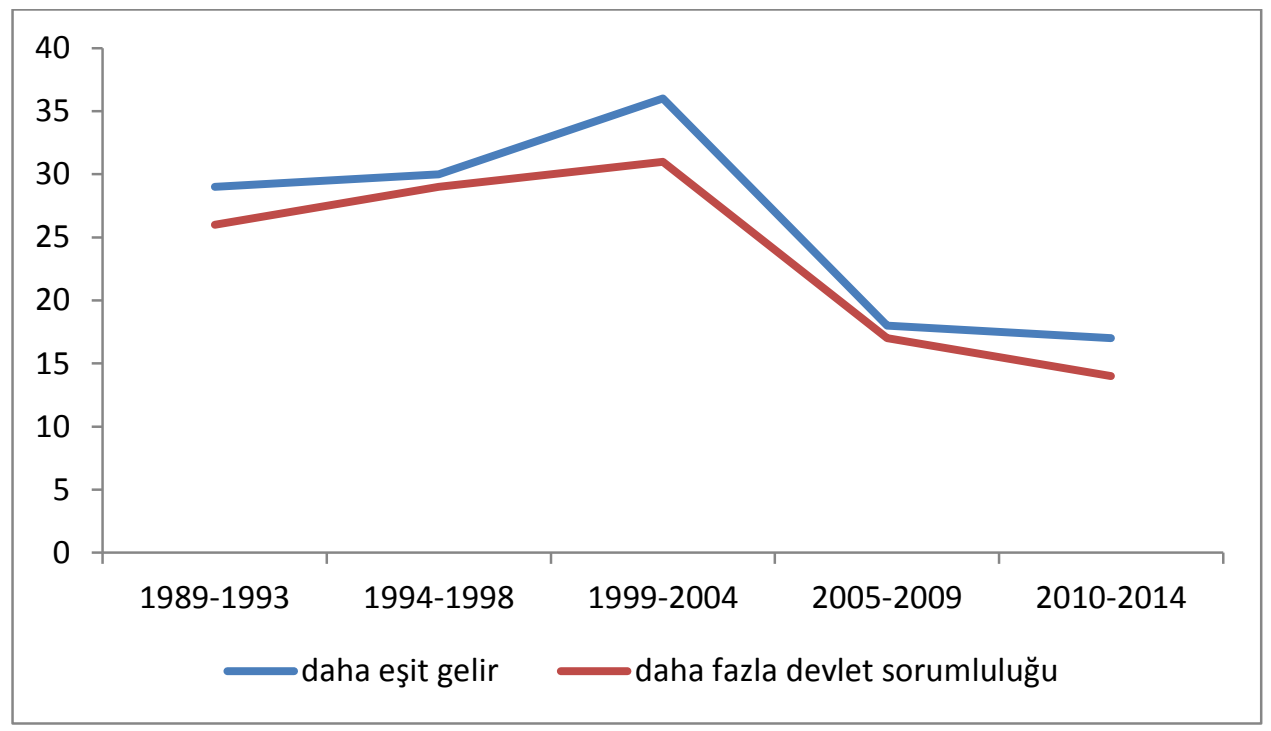

Kaynak: World Values Survey (1989-2011).

Çalışmada yukarıdaki değişimler öznel sosyal sınıf konumu ile açıklanmaktadır. Bireyler Türkiye'de özellikle 2000'lerin ortasından bu yana kendilerini orta sınıfa ait görmekte ve alt sınıftan uzaklaşmaktadır. Üstelik orta sınıf aidiyetindeki bu artış emek piyasaları ya da gelir dağılımındaki değişimlere dayanmamaktadır. Şekil: 2'den görülebileceği gibi en üstteki sınıfta kendini görenlerin payı yıllar içerisinde \%2'de sabitken işçi sınıfının oranı \%43'ten \%26'ya gerilemiştir. Alt sınıfa ait olduklarını söyleyenlerin oranında da \%9'dan \%5'e bir düşüş bulunmaktadır. Daha önce işçi sınıfına ve alt sınıfa mensup olduğunu söyleyen bazı bireyler giderek kendilerini daha fazla orta sınıf olarak nitelendirmekte ve gelir dağılımı ile ilgili tercihlerini de ona göre belirlemektedir. 1990'ların ortasından 2011'e kadar Türkiye'de kendini orta sınıf (üst orta ve alt orta birlikte) kabul edenlerin oranı \%47'den \%67'ye yükselmiştir ki bu oldukça hızlı bir artış olarak 
nitelendirilebilir. Aynı dönemlerde ankete katılanlar arasında çalışanların oranı \%41'de sabit kalırken gelir dağılımında da önemli bir iyileşme gözlenmemiştir. Dolayısıyla kişilerin kendilerini orta sınıfa ait görmelerinin ardında nesnel ekonomik sebeplerden ziyade öznel bazı sebepler öne çıkmaktadır fakat bu sebeplerin detayları çalışmada ele alınmamıştır.

Şekil: 2

Öznel Sınıf Konumu

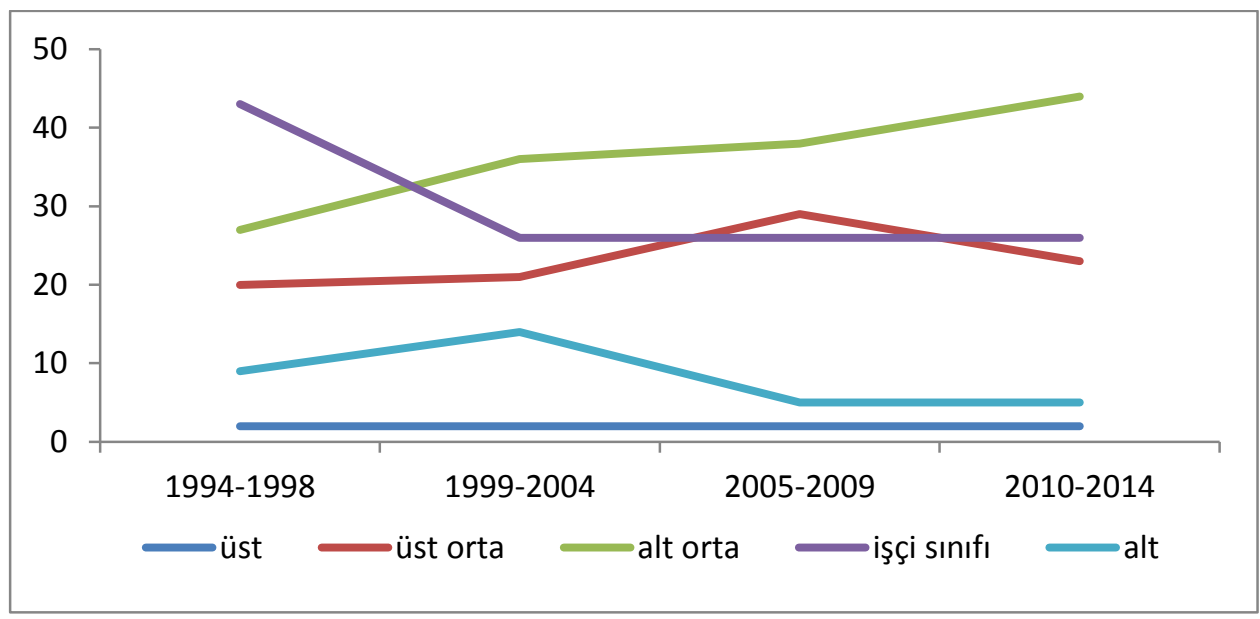

Kaynak: World Values Survey (1989-2011).

Türkiye'de anketlerin yapıldığı dönemde gözlenen bir başka ilginç değişim ise kişilerin siyasi görüşlerine ilişkindir. Şekil 3 1980'lerin sonundan 2011 yılına kadar kendini merkezin solunda, merkezde ve merkezin sağında görenlerin oranını göstermektedir. Kendini merkezin solunda tanımlayanlar bu dönem içerisinde \%25'ten \%20'ye gerilerken kendini merkezde görenlerin oranı ise $\% 51$ 'den $\% 31$ 'e kadar düşmüştür. Oysa kendini merkezin sağında görenlerin payı aynı yıllar içerisinde \%24'ten \%49'a yükselmiştir. Öznel siyasi konumdaki bu büyük değişim diğer bazı gelişmekte olan ülkelerde gözlenmemektedir. 
Şekil: 3

Öznel Siyasi Konum

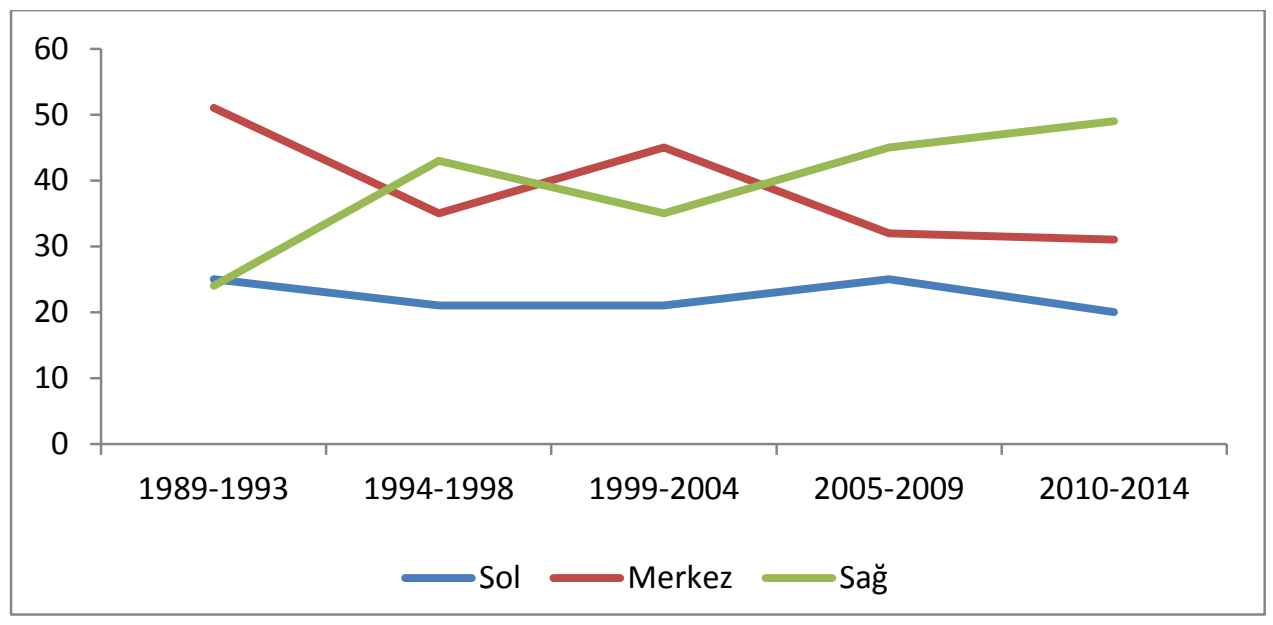

Kaynak: World Values Survey (1989-2011).

\section{Yöntem ve Veri Seti}

Çalışmadaki bağımlı değişkenin kesikli ve sıralı olmasından dolayı kantitatif tercih modellerinden sıralı probit modeli kullanılmıştır. Bu tür modellerde gözlenebilir, aralıklı ve sıralı kategorilerin ardında $\left(Y_{i}\right)$ sürekli ama gözlenemeyen bir bağımlı değiş̧ken olduğu varsayılmaktadır. Gizli (latent) bağımlı değişken $\left(\mathrm{Y}_{\mathrm{i}}^{*}\right)$ gözlenebilir bağımsız değişkenler vektörü $\left(\mathrm{X}_{\mathrm{i}}\right)$ ve normal dağılıma sahip hata terimi $\left(\varepsilon_{\mathrm{i}}\right)$ ile açıklanmaktadır (Greene, 2002). Bu durumda regresyon eşitliği aşağıdaki biçimde ifade edilebilir:

$Y_{i}^{*}=\alpha+\beta X_{i}+\varepsilon_{i}$

Burada $Y_{i}^{*}$ bireylerin ekonomik eşitsizlikler hakkındaki görüşleri iken $X_{i}$ nesnel ve öznel açıklayıcı değişkenleri kapsamaktadır. Sıralı probit modelinde bağımlı değişken $\left(\mathrm{Y}_{\mathrm{i}}\right)$ ve gizli bağımlı değiş̧ken $\left(\mathrm{Y}_{\mathrm{i}}{ }^{*}\right)$ arasındaki ilişki bireylere göre farklı değerler almakta ve regresyon katsayıları $(\beta)$ kullanılarak tahmin edilen eşik değerlerin $\left(\mu_{\mathrm{j}}\right)$ bir fonksiyonudur. Araştırmada bireyler ekonomik eşitsizlikler hakkındaki görüşleri için 1'den 10'a kadar seçim yapabildikleri için bağımlı değişken 10 farklı değer alacak şekilde sıralanmıştır. Bireylerin alternatiflerden birini seçme olasılığı aşağıdaki gibidir: 


$$
\operatorname{Pr}\left(\mathrm{Y}_{\mathrm{i}}=1 / \mathrm{X}_{\mathrm{i}}\right)=\Phi\left(\mathrm{X}_{\mathrm{i}} \beta\right)
$$

Bu değer, X bağımsız değişken vektörü verildiğinde bağımlı değişken Y'nin 1 olma olasılığını ifade eder. Burada $\Phi$ standart normal olasılık dağılımıdır. $\beta X$ probit skoru ya da indeksi olarak adlandırılır ve normal dağılıma sahiptir. $0<\mu_{1}<\mu_{2}<\ldots<\mu_{\mathrm{j}-1}$ koşulu sağlandığı sürece tüm olasılıklar pozitiftir. Probit katsayısı $\beta$, tahmindeki bir birimlik bir yükselmenin probit skorunda ( $\mathrm{z}$ standart değerinde) yapacağı $\beta$ standart sapmalık yükselmeyi ifade eder. Örneğin, sosyal sınıfında bir alt ya da üst kategoriye çıkmanın gelir dağılımı tercihlerinde referans kategoriye göre nasıl bir etki yarattığına bakar.

Analizlerde kullanılan veriler Dünya Değerler Anketi'nden (World Values Survey) elde edilmiştir. Bu anket birçok gelişmiş ve gelişmekte olan ülkede farklı zaman dilimlerinde yapılmaktadır. Var olan uluslararası anketler arasında hem coğrafi alan hem de sorulan soruların içeriği açısından en kapsamlı olanlarındandır. Katılımcıların siyasi, ekonomik ve sosyal tercihleri ile demografik bilgileri mevcuttur. Anket ilk olarak 1986 yılında yapılmıştır fakat çok az sayıda gelişmekte olan ülke ankete katılmıştır. Türkiye için anket 1989-2011 yılları arasında toplam beş kez tekrarlanmıştır. Bu dönem bir çok gelişmekte olan ülkede yaşanan siyasi, ekonomik ve sosyal gelişmeler açısından yol göstericidir ve araştırma için yeterli uzunlukta bir periyot sağlamaktadır.

Eşitsizlik toleransını hesaplamak için anketlerde sorulan bir sorudan doğrudan faydalanılmıştır. Bu soru katılımcılara gelirlerin daha eşit mi dağılması gerektiğini yoksa insanları çalışmaya motive etmek için gelir eşitsizliğinin gerekli olup olmadığını sormaktadır. 1'den 10' kadar olan sıralamada katılımcılar bu fikirlerin herhangi birini ne derecede onayladıklarını belirtebilmektedirler. Buna göre 1 daha eşit bir gelir dağılımına tümüyle katılmak anlamına gelirken 10 toplumda daha fazla gelir farkı olmasının faydalı olacağı düşüncesini benimsemek anlamına gelmektedir. Aradaki değerler ise katılımcıların hangi uçtaki fikre daha yakın durduğunu göstermektedir. İstatistiki testlerinin sağlamlığı için bireysel ya da devlet sorumluluğu hakkındaki fikirleri ölçen bir soru da kullanılmıştır. Bu soruda katılımcılara herkes için asgari hayat şartlarını sağlamakla devletin mi yükümlü olduğu yoksa bu sorumluluğun yalnızca kişiye ait mi olduğu sorulmaktadır. Yine yukarıdakine benzer biçimde 1'den 10'kadar bir sıralama vardır ve düşük değerler bireylerin sorumluluğu düşüncesine katılımı işaret etmektedir.

Bağımlı değişken olarak kullanılan her iki soru da bireylerin öznel seçimlerine bakmaktadır ve nesnel koşullar kontrol değişkenleri ile regresyona eklenmiştir. Daha önceki çalışmalarla karşılaştırmayı mümkün kılmak bakımından gelir düzeyi, ideoloji, cinsiyet, eğitim, emek piyasasındaki konum, meslek kolu ve din gibi sıkça ele alınan faktörler bu incelemeye dâhil edilmiştir. Tüm bu bağımsız değişkenlere dair veriler bahsi geçen anketlerden derlenmiştir. Bu çalışmanın temel açıklayıcı değişkeni olan öznel sınıflar da 
yine aynı ankette sorulan bir sorudan elde edilmiştir. Ankete katılan bireylere kendilerini hangi sosyal sınıfa ait gördükleri sorulmuş ve üst, üst orta, alt orta, işçi ve alt sınıf olmak üzere beş kategori arasında seçim yapmaları istenmiştir. Regresyonlarda üst ve alt orta sınıflar ile işçi ve alt sınıflar birleştirilerek üç kategori analize tabi tutulmuştur. Tablo 1 ampirik analizde kullanılan bağımsız değişkenlerin ayrıntılarını sunmaktadır.

\section{Tablo: 1 \\ Kullanılan Bağımsız Değişkenler}

\begin{tabular}{|l|l|}
\hline \multicolumn{1}{|c|}{ Değişken } & \multicolumn{1}{c|}{ Açıklama } \\
\hline Yaş & Katılımcıların yaşlarına göre 0 (genç) - 3 (yaşlı) değerlerini alan değişken. \\
\hline Cinsiyet & Katılımcıların cinsiyetlerine göre 0 (erkek) - 1 (kadın) değerlerini alan değişken \\
\hline Gelir Durumu & Katılımcıların ait oldukları gelir grubuna göre 1-5 arasında değer alan değişken \\
\hline $\begin{array}{l}\text { Emek Piyasası } \\
\text { Durumu }\end{array}$ & $\begin{array}{l}\text { Katılımcıların emek piyasasındaki konumlarına göre 0-3 arası değer alan değişken. 0 işgücüne } \\
\text { dâhil olmayanlar bireyleri temsil etmektedir. }\end{array}$ \\
\hline İdeoloji & $\begin{array}{l}\text { Katılımcıların kendilerini siyasi olarak sol-sağ skalasında gördükleri yere bağlı olarak 1 (sol) } \\
-10 \text { (sağ) arasında değerler alan değişken }\end{array}$ \\
\hline Eğitim & $\begin{array}{l}\text { Katıllımcıların bitirdikleri okula göre 0 (eğitimsiz) - 4 (üniversite mezunu) arasında değerler } \\
\text { alan değişken }\end{array}$ \\
\hline Dindarlık & $\begin{array}{l}\text { Katılımcıların dinin hayatlarında önemli olarak görmelerine göre 0 (önemsiz) - 4 (çok } \\
\text { önemli) arasında değerler alan değişken }\end{array}$ \\
\hline Sosyal Sınıf & $\begin{array}{l}\text { Katıllımcıların kendilerini ait gördükleri sınıfa göre 0 (üst sınıf) - 2 (alt sınıf) arasında değerler } \\
\text { alan değişken }\end{array}$ \\
\hline
\end{tabular}

Kaynak: World Values Survey (1989-2011).

\section{Araștırmanın Bulguları}

İlk olarak regresyon yöntemi ile Türkiye'de eşitsizlik tahammülünü açıklayan nesnel ve öznel faktörler incelenmiştir. Tablo 2'de sunulan 1 numaralı modelde yaş, cinsiyet, eğitim, istihdam durumu, dindarlık, gelir, ideoloji ve öznel sosyal sınıfların gelir dağılımına dair görüşleri nasıl etkilediğine bakılmıştır. Ayrıca regresyona anketin yapıldığı döneme dair bir değiş̧ken (kukla değişkeni) de eklenmiştir. 1. sütundan görüldüğü gibi yaş, gelir, ideoloji, sosyal sınıflar ve anket dönemi $\% 1$ düzeyinde açıklayıcı iken cinsiyet $\% 10$ düzeyinde açıklayıcıdır. Örneğin, gelir durumu ile gelir dağılımının daha adil olması gerektiği görüşü arasında ters bir orantı vardır ve kişiler ekonomik olarak zenginleştikçe yaklaşık olarak .07 nokta daha az gelir adaleti taraftarı olmaktadırlar. Sıralı probit hesaplamalarında katsayılar açıklayıcılık yönünden yeterince güçlü olmadıkları için bağımsız değişkenlerin marjinal etkilerine de bakmak gerekmektedir.

Tablo 3 tüm modeller için örneklem ortalamasına göre marjinal etkileri göstermektedir. Buna göre 1. modelde istatistiki olarak anlamlı yaş, cinsiyet, gelir, ideoloji, sosyal sınıflar ve anket döneminin marjinal etkileri de aynı güven aralığında etkilidir. 
Örneğin, gelir dağılımında bir dilimden diğerine geçiş gelir adaletsizliğine daha fazla tahammül edebilme olasılığını yaklaşık olarak \%3 yükseltmektedir. İlginç bir nokta katılımcıların dinin hayatlarındaki önemi arttıkça adil bir gelir dağılımı tercihlerinin azalmasıdır, dindarlık değişkeninin katsayısı yaklaşık .2 olarak ölçülmüştür ve \%1 düzeyinde anlamlıdır. Aynı değişkenin marjinal etkisi de neredeyse $\% 8$ olarak hesaplanmıştır.

Tablo: 2

Siralı Probit Hesaplamaları

\begin{tabular}{|c|c|c|c|}
\hline & \multicolumn{3}{|c|}{ Katsayı } \\
\hline & $(1)$ & $(2)$ & (3) \\
\hline Yaş & $-.1044992 * * *$ & $-.1033097 * * *$ & $-.0910237 * * *$ \\
\hline Cinsiyet & $-.0567182^{*}$ & $-.0574237 *$ & -.0447426 \\
\hline Eğitim & .0033208 & .0046631 & -.0037591 \\
\hline İstihdam Durumu & -.0408164 & -.0425735 & -.0245689 \\
\hline Dindarlık & $.1922117 * * *$ & $.1919849 * * *$ & $.2000675 * * *$ \\
\hline Gelir & $.0679481 * * *$ & $.0688016^{* * * *}$ & $.0668774 * * *$ \\
\hline İdeoloji & $.1528366^{* * * *}$ & $.1535409 * * *$ & $.1499987 * * *$ \\
\hline Sinıf & $-.1399754 * * *$ & & \\
\hline Orta & & $-.2947041 * * *$ & \\
\hline Alt & & $-.416998 * * *$ & \\
\hline Anket Dönemi & $.0785221 * * *$ & $.0778122 * * *$ & \\
\hline Sınıf ve Anket Dönemi & & & \\
\hline 01 & & & .1168317 \\
\hline 02 & & & .1564291 \\
\hline 03 & & & $.2960601 *$ \\
\hline 10 & & & $-.305741 * * *$ \\
\hline 11 & & & $-.2909582 * * *$ \\
\hline 12 & & & -.1818459 \\
\hline 13 & & & -.0368448 \\
\hline 20 & & & $-.5458844 * *$ \\
\hline 21 & & & $-.5625451 * * *$ \\
\hline 22 & & & $-.5355327 * * *$ \\
\hline 23 & & & $-.4706065 * * *$ \\
\hline Log likelihood & -6565.3246 & -6564.2076 & -6524.1071 \\
\hline Pseudo R2 & 0.114 & 0.116 & 0.176 \\
\hline Gözlem Sayısı & 6673 & 6673 & 6673 \\
\hline
\end{tabular}

$p^{*}=.1, p^{* *}=.05$ ve $p^{* * *}=.01$

Regresyonda en yüksek katsayılar ve marjinal etkiler ideoloji ve sosyal sınıflara aittir. Hesaplamalarda referans sınıf üst sınıf olduğu için negatif işaret üst sınıftan alt sınıfa doğru hareket ettikçe gelirlerin daha eşit olması gerektiği fikrine daha fazla katılma şansı olduğunu göstermektedir. Sosyal sınıf değişkeninin katsayısı -.14 iken ideoloji değişkeninin katsayısı .15 civarındadır. Marjinal etkilere bakıldığında sol görüşten sağ görüşe kayışın 
katılımcıların gelir eşitliği fikrine katılma olasılıklarını \%6 oranında azalttığı hesaplanmıştır. Üst sınıftan alt sınıfa geçiş ise bağımlı değişkeni neredeyse \%6'lık oranla etkilemektedir.

2. modelde diğer bağımsız değişkenler sabit kalırken sosyal sınıfların her birinin gelir dağılımı görüşleri ile arasındaki ilişki incelenmiştir. Yaş, cinsiyet, dindarlık, gelir, ideoloji ve anket dönemleri hem katsayılarını hem de istatistiki önemlerini bu modelde korumaya devam etmiştirler. Orta sınıfın katsayısı .03 olarak ölçülürken alt sınıfın katsayısı yaklaşık .04 olarak hesaplanmıştır. Buna göre referans kategorisi olan üst sınıflara oranla hem orta hem de alt sınıflar daha adil bir gelir dağılımı tercihi yapmaktadırlar. Her iki değişken \%1 düzeyinde anlamlıdır. Marjinal etkilere bakıldığında üst sınıftan orta sınıfa geçildiğinde gelir dağılımı daha eşit olmalı fikrine katılma olasılığ $\%$ 11, üst sınıftan alt sınıfa geçildiğinde ise \%16 oranında artmaktadır. Diğer bağımsız değişkenler marjinal etki önemlerini bu modelde korumuşturlar. Anket dönemleri ekonomik eşitlik ile ilgili görüşlerin zamana bağlı olduğunu ve ilk anketle karşılaştırıldığında daha sonraki dönemlerde katılımcıların adil bir dağılım isteme olasılıklarının \%3 düştüğünü göstermektedir.

Son modelde sosyal sınıfların anket dönemleri ile birlikte etkisine bakmak için etkileşim değişkenleri oluşturulmuş ve her bir sosyal sınıf ile her bir dönemin ortak etkisi referans kategori ile karşılaştırılmıştır. Bu modelde temel açıklayıcı için referans kategori 1. anket dönemindeki üst sınıf katılımcılardır. Buna göre anket dönemleri ya da zaman içerisinde üst sınıflar giderek daha az eşitlik talep eder olmuşturlar fakat sadece üst sınıf ve son dönem değişkeninin katsayısı .3'lük bir değer ile \%10 düzeyinde anlamlıdır. Orta sınıflar üst sınıflara göre tüm dönemler için adil bir gelir dağılımı olması görüşüne daha fazla katılmaktadırlar fakat katsayılar yalnızca 1 ve 2 . anket dönemleri için istatistiki olarak anlamli ve sirasiyla .3 ve .29 'tur.

Marjinal etkilere bakıldığında da benzer sonuçlar çıkmaktadır. Üst sınıftan orta sınıfa geçiş sadece 1. ve 2. dönemler için açıklayıcı iken 3. ve 4. dönemler için istatistiki olarak gelir eşitliği talebini etkilememektedir. 1. anket döneminde orta sınıftan birinin bir önceki dönemde üst sınıftan birine göre adil bir dağılım isteme olasılığı $\% 42$ oranında artarken 3. dönemde bu etki \%21'e gerilemekte ve istatiski olarak anlamsız kalmaktadır. Alt sosyal sınıfa bakıldığında ise tüm dönemler için anlamlı ve üst sınıfa nazaran daha fazla gelir adaleti talebi gözlenmiştir. Üst gelir grubundan birinin alt gelir grubuna doğru gidildikçe, örneğin 4. dönemde bile gelirlerin daha eşit olması gerektiğini söyleme olasılığı yaklaşık $\% 60$ oranında artmaktadır. 
Tablo: 3

\section{Marjinal Etkiler}

\begin{tabular}{|c|c|c|c|}
\hline & \multicolumn{3}{|c|}{ dydx } \\
\hline Yaş & $.0409475^{* * *}$ & $.0404733^{* * *}$ & $.0353564 * * *$ \\
\hline Cinsiyet & $.0222248^{*}$ & $.0224967^{*}$ & .0173794 \\
\hline Eğitim & -.0013013 & -.0018268 & .0014601 \\
\hline İstihdam Durumu & .0159937 & .0166789 & .0095433 \\
\hline Dindarlık & $-.0752233 * * *$ & $-.0751196 * * *$ & $-.0776084 * * *$ \\
\hline Gelir & $-.0266251 * * *$ & $-.0269542 * * *$ & $-.0259772 * * *$ \\
\hline İdeoloji & $-.0598883^{* * * *}$ & $-.0601522 * * *$ & $-.0582641 * * *$ \\
\hline Sinıf & $.0548487 * * *$ & & \\
\hline Orta & & $.1149364 * * *$ & \\
\hline Alt & & $.1629431 * * *$ & \\
\hline Anket Dönemi & $.0307685 * * *$ & $.0304842 * * *$ & \\
\hline Sinıf ve Anket Dönemi & & & \\
\hline 01 & & & -.3593444 \\
\hline 02 & & & -.3447899 \\
\hline $\mathbf{0 3}$ & & & -.519411 \\
\hline 10 & & & $.4255718 * * *$ \\
\hline 11 & & & $.4173975 * * *$ \\
\hline 12 & & & .2138003 \\
\hline 13 & & & .2745984 \\
\hline 20 & & & $.4995957 * * *$ \\
\hline 21 & & & $.6226978 * * *$ \\
\hline 22 & & & $.4170974 * * *$ \\
\hline 23 & & & $.5876592 * * *$ \\
\hline
\end{tabular}

Öngörülen marjlar tüm katılımcıların bir grupta olması halinde bağımlı değişkenin tahmin edilen değerini alma olasılığını göstermektedir. Şekil 4'te görüldüğü gibi sosyal sınıfların anket dönemleri içerisinde öngörme marjları değişim göstermiştir. Oysa Şekil 5 ve 6'daki gelir ve ideoloji değişkenlerinin tahmin güçlerinin büyüklükleri zaman içerisinde değişse de sıralamaları aynı seyirdedir. Örneğin, anket yapılan ilk dönemde katılımcıların gelirler daha eşit olmalıdır fikrini söyleme olasılığı herkesin en alt gelir grubunda olması halinde \%50'ye yakınken herkesin en üst gelir grubuna ait olduğu durumda aynı dönemde bu cevabı verme olasılığ $1 \% 36$ civarındadır. Diğer tüm değişkenlerin değerleri örneklem ortalamalarında sabitlenmiştir. 
Şekil: 4

Sosyal Sınıfların Dönemler İçindeki Öngörü Marjları

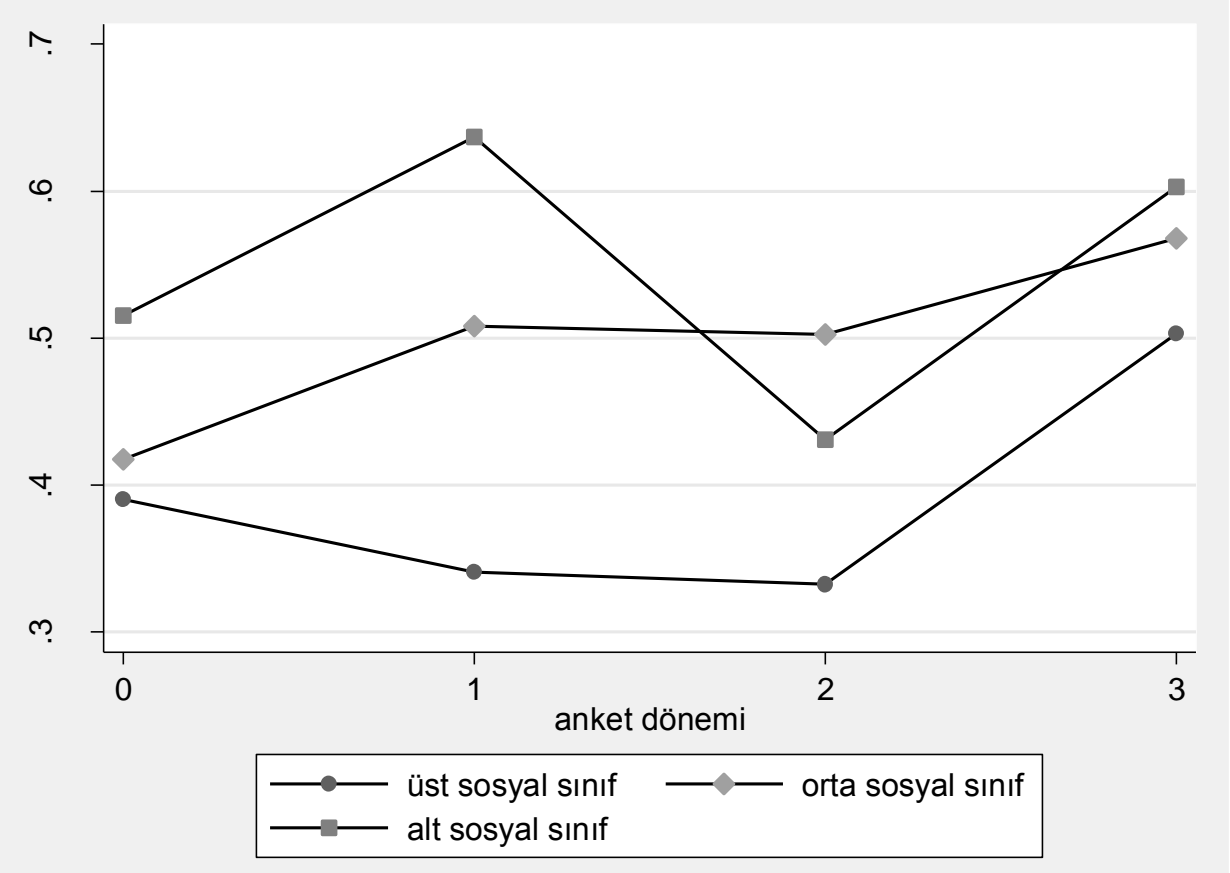




\section{Sekil: 5}

\section{Gelirin Dönemler İçindeki Öngörü Marjları}

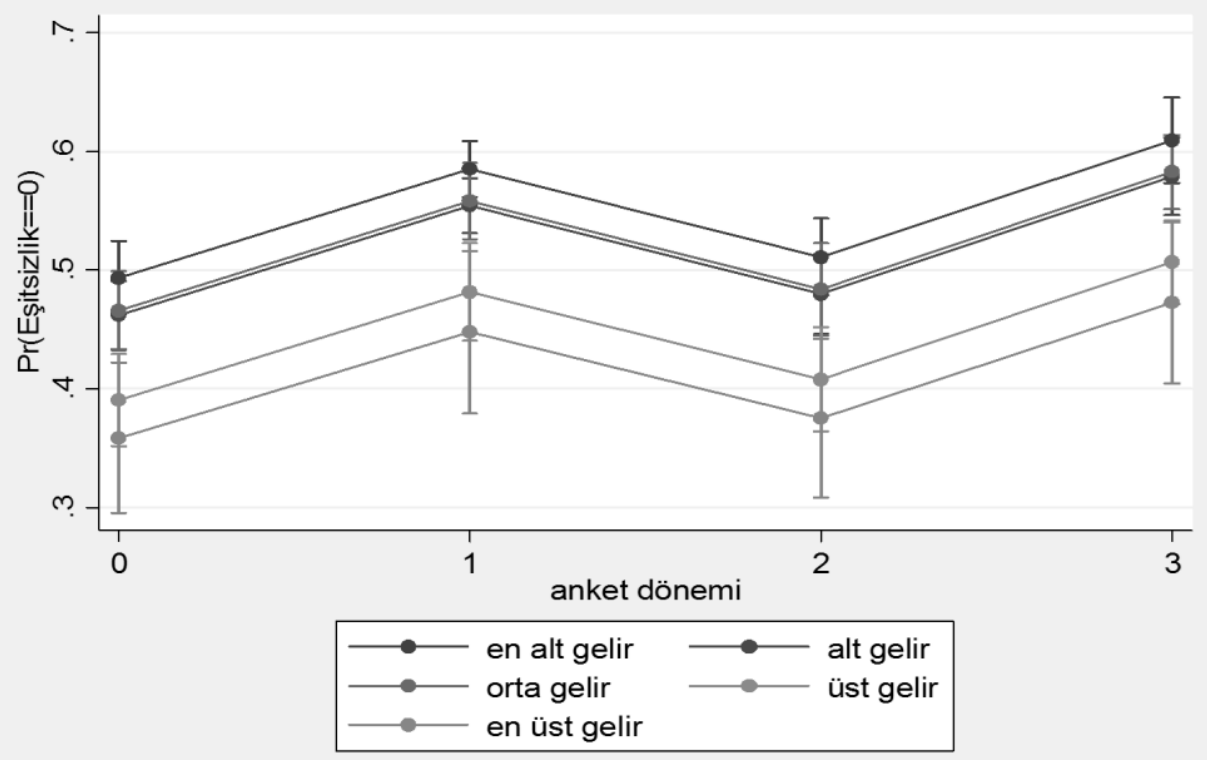




\section{Şekil: 6 \\ İdeolojinin Dönemler İçindeki Öngörü Marjları}

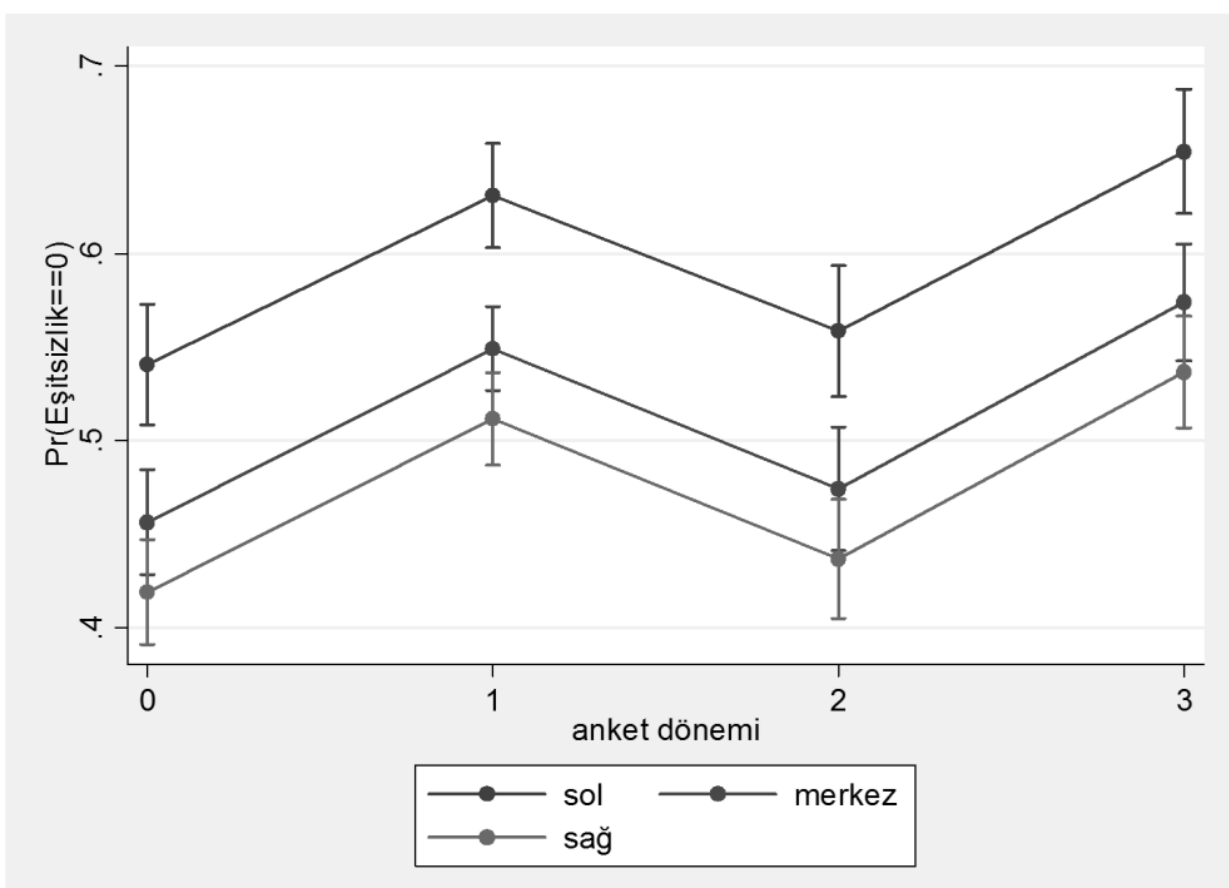

Oysa sosyal sınıflara bakıldığında öngörülen marjların zaman içerisinde hem büyüklükleri hem de sıralaması değişmiştir. Bu da sosyal sınıfların farklı dönemlerde farklı tercihlerde bulunduklarına işaret etmektedir. İlk anket döneminde üst ve orta sınıfların gelirlerin daha eşit olması gerektiği cevabını sırasıyla $\% 39$ ve $\% 42$ oranında etkilediği şekil 4 'ten görülmektedir. Aynı dönemde herkesin alt sınıfa mensup olması halinde ise daha adil bir gelir dağılımının tercih edilme olasılığ $1 \% 52$ civarındadır. Bir sonraki anket dönemine gelindiğinde ise sınıflar arasındaki farklar daha belirgin hale gelmiştir. Üst sınıfın öngörülen cevabı verme olasılığı düşerken orta sınıfın etkisi \%50'ye ulaşmıştır. Aynı zamanda alt gelir grubundakilerin de eşit gelir dağılımı isteme olasılıklarında artış gözlenmiş ve etki yaklaşık olarak \%63 olarak ölçülmüştür. 3. dönemde ise orta sınıfların etkisinde bir değişiklik gözlenmemiş̧ir fakat hem üst hem de alt sınıfların tahmin etme gücünde bir düşüş bulunmuştur. Özellikle alt sınıflar bu dönemde gelir dağılımının daha eşit olması gerektiği cevabını verme olasılığını yalnızca \%44'ler düzeyinde etkilemektedir. Aynı zamanda orta sınıfların bu cevabı verme olasılığına etkisinin altında kalmaktadır. Son dönemde alt ve üst 
sınıfların etkisinde hızlı bir artış, orta sınıfların etkisinde ise görece daha yavaş bir yükseliş vardır. Alt sınıfın tahmin marjı \%60'lar civarına çıkarken orta sınıfın tahmin marjı \%58 seviyelerine ulaşmıştır. Üst sınıfların tahmin değeri de neredeyse \%50'ye yükselmiştir ki bu da özellikle son dönemde daha önceki yıllara göre sınıflar arası farkların giderek azaldığını ortaya koymaktadir.

Tüm bu dalgalanmalar bize Türkiye'de anketlerin yapıldığı dönemler arasında sosyal sınıfların gelir dağılımı hakkındaki görüşlerinin değiştiğine işaret etmektedir. Bu dönemde Türkiye'de sadece alt sınıflardan orta sınıflara doğru öznel bir kayış değil aynı zamanda sınıflar içerisinde de tercih farklılıkları oluşmuştur. Giderek daha çok bireyin kendini orta sınıfa ait görmesi gelir ve emek piyasasındaki durumları gibi nesnel göstergeler tarafından açıklanamamaktadır. Fakat bu sebeplerin derinine inmek bu çalışmanın kapsamını aşmaktadır. Sosyal sınıflar kişilerin gelir adaleti hakkındaki fikirlerini ehr dönemde etkilemektedir ve çalışmanın ampirik bulgularına göre bu etki zaman içerisinde farklılık göstermiştir.

\section{Sonuç ve Öneriler}

Bu çalışmada Türkiye'de eşitsizlik tahammülünün bireysel düzeyde hangi faktörlerle açıklanabileceğine ve zaman içerisindeki seyrine bakılmıştır. Türkiye'de gelir dağılımının daha adil olması gerektiği görüşüne katılanların oranı yıllar içerisinde azalmıştır. Aynı dönemde sosyal sınıf dağılımında da önemli değişimler gözlenmiştir. Çalışmanın ampirik sonuçlarına göre ülkede yıllar içerisinde kendini orta sınıfta görenlerin oranının artması ile birlikte gelir dağılımının hakkındaki görüşler de değişmiş ve daha adil bir gelir dağılımı tercihi önceki dönemlere göre gerilemiştir. Kamusal tercihlerin sosyal politika yapımında önemli rol oynayabileceği düşünüldüğünde kimin ne tür ekonomik programları desteklediğini anlamak yararlı olabilir. Ayrıca ilerideki çalışmalarda bireylerin neden kendilerini nesnel sosyo-ekonomik durumlarından bağımsız olarak orta sınıfta tanımladıklarına bakmak da gereklidir.

\section{Kaynakça}

Ardanaz, M. (2009), "Preferences for Redistribution in the Land of Inequalities", Unpublished manuscript, Columbia University.

Armingeon, K. (2006), "Reconciling Competing Claims of the Welfare State Clientele, The Politics of Old and New Social Risk Coverage in Comparative Perspective", K. Armingeon and G. Bonoli (eds.), The Politics of Post-Industrial Welfare States, Adapting Post-War Social Policies to New Social Risks, London: Routledge, 100-122.

Benabou, R. \& E. Ok (2001), "Social Mobility and the Demand for Redistribution: the POUM hypothesis”, Quarterly Journal of Economics, 116(3): 447-87. 
Breen, R. (2004), Social Mobility in Europe, Oxford: Oxford University Press.

Dion, M. (2010), "When is it Rational to Redistribute? A cross-national examination of attitudes toward redistribution", Unpublished manuscript.

Duman, A. (2009), Political Support for Social Insurance: how important are labor market risks?, Saarbrucken: VDM Verlag.

Gijsberts, M. (2002), “The Legitimation of Income Inequality in State-Socialist and Market Societies", Acta Sociologica, 45(4): 269-285.

Greene, W.H. (2002), Econometric Analysis, $5^{\text {th }}$ ed., New York, NY: Prentice Hall.

Hout, M. (2008), "How Class Works: Objective and Subjective Aspects of Class Since the 1970s", in: A. Lareau \& D. Conley (eds.). Social Class: How Does It Work?, New York, NY: Russel Sage, 25-64.

Luttmer, E.F.P. (2001), “Group Loyalty and the Taste for Redistribution”, Journal of Political Economy, 109: 500-528.

Meltzer, A.H. \& S.F. Richard (1981), "A Rational Theory of the Size of Government". Journal of Political Economy, 89(5): 914-27.

Moene, K.O. \& M. Wallerstein (2001), “Inequality, Social Insurance, and Redistribution”, American Political Science Review, 95(4): 859-74.

Patti, D.M. \& P. Navarro (2010), "Endogenizing Fairness to Explain Preferences for Redistribution”, Unpublished manuscript.

Ravallion, M. \& M. Lokshin (2000), "Who Wants to Redistribute? The tunnel effect in 1990s Russia", Journal of Public Economic, 76: 87-104.

Suhrcke, M. (2001), "Preferences for Inequality: East vs. West", Innocenti Working Papers, No: 89, Florence. 